\title{
Modernizing Dairy Farm: A Production Mode Analysis
}

\author{
St. Aisyah R ${ }^{\mathrm{a}}$, Darmawan Salman ${ }^{\mathrm{b}}$, Ahmad Ramadhan Siregar ${ }^{\mathrm{c}}$, Syahdar Baba ${ }^{\mathrm{c}}$ \\ ${ }^{a}$ Department of Agriculture Sciences, Hasanuddin University, Indonesia \\ E-mail: st.aisyah@unismuh.ac.id \\ ${ }^{b}$ Department of Agribusiness, Faculty of Agriculture, Hasanuddin University, Indonesia \\ E-mail:darsalman1963@gmail.com \\ ${ }^{c}$ Department of Socio-Economic, Faculty of Livestock, Hasanuddin University, Indonesia \\ E-mail: ahmadramadhan_siregar@yahoo.com,syahdarbaba@gmail.com
}

\begin{abstract}
Appearing livestock modernity due to a greater dependency on the market and actions follows the capitalistic logic of production. This study focuses on the mode of production in developing dairy cattle in the modernity era. Data collection was carried out through observations, recordings, and deep interviews for key informants using the snowball technique. The data were compiled in forms of field notes and audio records transferring into written transcription. Those data were then analyzed using thematic analysis. This study found out that the forces of production in dairy farms are based on simple technology, and subsistence needs orientation. Also, this study becomes aware of the social relations of production in dairy farms are based on a low division of labor and combine morality and rationality based on production organizations. Thus, the mode of production of dairy farming is a noncapitalistic. This research contributes to the modernization theory that the modernization process is not always displayed by changes from non-capitalistic to capitalistic modes of production. It is expected that dairy farming is no longer considered a side job, but is a promising and attractive job for the younger generation. Thus, this condition encourages the emergence of young breeders who certainly have better abilities than the current breeders. The increasing entrepreneurial spirit of farmers, it is expected to have an impact on increasing income and employment. Production mode also plays an essential function to assist in increasing output per labor unit. Labor productivity is projected to rise through innovation and technology.
\end{abstract}

Keywords_mode of production; livestock; dairy cattle; modernity.

\section{INTRODUCTION}

The agricultural sector development, including livestock, is one of the strategic choices to support national and regional economies [1]. Based on data obtained from The United States Department of Agriculture (USDA) contained in the reference [2] that the average of the world cattle population in the last five years is about 139.18 million individuals with a growing exceeding $1.39 \%$ annually. The report also said that a high enough growth spurt occurred in 2014 with a $1.9 \%$ increase comparing with previous years, and the lowest growth happened in 2016 with $0.89 \%$ than in 2015. Besides, the report also said that the demands of fresh milk and its derived products are predicted to increase in line with human population growth, economic development, improving education, nutrition awareness, and lifestyle changes.

To maintain a dairy cow must be well prepared. In addition to maintaining cleanliness, it requires to consider the comfort of cows. Because to get the milk that many dairy cows should not be stressed, must be in a relaxed state. The more comfortable the condition of the cow, the higher the milk productivity. The height of the cage recommended for raising dairy cows is around 4-4.5 meters. The structure of the cage must be made of strong materials, can be iron, wood, or bamboo. The floor of the cage should be made in strong and clean materials that do not cause harm to cows. The floor must be comfortable to use for lying down. The ground floor is not recommended for raising dairy cows. Places to eat and drink must be designed so that cows can easily access it but cannot trample on it. Then the drainage or drainage of water and sewage. Dairy cows demand cleaning the cage every time. Therefore, drains and sewage must be absolutely smooth.

The market dependence and actions following the capitalistic logic of production causes arising a livestock modernization [3]. The dairy farm seldom undergoes substantial modernization in commercial milk production affecting by geographical location, season, and raw material prices (feed, electricity, and fuels) [4]. In promoting the modernization of agriculture, some important considerations 
that need to be considered like obeying local condition, utilizing comparative advantages, and exploring actively in establishing modern agriculture [5]. The modernizing project is conducted to investigate milk production and labor efficiency [6]. The main components of modernization are to spread cattle feed plants and to adjust structural changes of agriculture, including plant variation [7]. One of the mechanisms to decrease the poverty level is through agricultural modernization that can escalate agricultural productivity and incomes of poor people in rural areas [8].

In some countries, previous researches reviewing the planning modes of manufacturer production, modes of sustainable industrial production, optimizing distribution with various modes of production and prices, and supply chain strategic coordination of production [9]-[13]. However, there is not any study yet to explore in the global context of the mode of production in developing dairy cattle raising in the modernity era. Aims of this research were to analyze the force of production and the social relations of production. Thus, the results of this study will contribute to the theory of modernization.

Starting a dairy cattle business in Indonesia is tricky. Indonesia has a tropical climate, but the types of dairy cows that circulate mostly from the sub-tropical regions. So we need specific tips so that the dairy cow business runs successfully. The purpose of the dairy cattle business is to take milk. Considering the nature of the product, dairy cattle must prioritize sanitation, both sanitation enclosure and sanitation of the livestock itself, unlike the case with beef cattle that focus on rearing. In Indonesia, the cultivation of dairy cows is more suitable to be carried out in the mountains, which have a cool climate. Because most types of productive dairy cows are cows from sub-tropical regions with cold climates, dairy cows can still be cultivated in hot lowlands, but milk production is not optimal.

\section{MATERIALS AND METHOD}

Data were collected by observation, recording, and deep interviews for key informants using the snowball technique. The key informants possess knowledge on how to develop dairy farms and communities' conditions in the Enrekang Regency, Indonesia. Further, compiling the collected data in forms of field notes and audio records transferring into the written transcripts. In order to have an accurate transcription result, repeating checks the audiovisual recordings to validate the data [14], [15].

Data were analyzed using thematic analysis [15], [16], to conduct this, the patterned themes were identified, consisting of six steps as follows:

- Collecting data.

- Coding data.

- Identifying themes.

- Reviewing themes.

- Naming themes.

- Reporting production.

The authors identified codes and themes using a concept that criteria in identifying key themes consists of same themes [17], as follows:

- A relevance with the research objectives.

- Frequency theme
- Excellence of the same theme in various types of participants.

Furthermore, the authors checked the codes and themes as well as compromising together to find an agreement and to lower potential errors. Based on the collective agreement, the authors identified themes related to the mode of production of dairy farming. A qualitative method is useful to identify and analyze various ways of looking at topics [18].

\section{RESUlTS AND DISCUSSION}

The results of this study are described in two parts, namely the force of production and the social relations of production. The force of production is discussed in two themes, namely the technology of production and orientation of production. Then, the social relations of production are discussed in two themes, namely the division of labor and relations in production organizations.

\section{A. The Force of Production}

1) Production technology: A technology of production is a technology used in the production management system. It composes land, production materials such as feed; cattle; production tools; and knowledge applying into the production process. The informant frequently talks about the technology of production where land use originated from agricultural commodity land are the most common responses in this research:

\begin{abstract}
"Initially, I established a cow cage beside my house; however, due to the cow's population grew continuously and had a wrong view because of my cowshed was located near to a road now. I eventually moved it near to a river where the land of the new cowshed belongs to my parents. That current grassland, I planted it formerly with corn and chocolate plants. But the results I receive in raising grass is more than corn (NS, Farmer 1).
\end{abstract}

From the interviews, the informants used ex-agricultural land for their dairy farming business. The land is part of the technology of production. Land needs for the development of dairy cattle are very important, especially as forage production.

"For myself, feed is the biggest cost component (60-80\%)
in this dairy cattle farming business. In the dry season,
the forage is difficult to be found that should be changed
with the same feed, namely paddy straws or corn straws.
Additional feeds seldom are bought in BUMDES (Badan
Usaha Milik Desa, A Business Entities Belongs to a
Village), or I buy them by myself to other cattle owners
due to each cattle owner has its own market network for
purchasing additional feeds" (AW, Farmer 4).

From interviews, informants used fodder (see Fig. 1) by relying on simple local feed ingredients. Informants take advantage of local feed potential both during the rainy season and the dry season, as well as the harvest season.

"In the beginning, the breed of cow species that was developed in Enrekang Regency was the Sahiwal crossbreed, the amount of milk was not abundant with an average production of only 4 - 6 liters/day. After the 
2000s, it turned into the breeds of Holstein Friesian cattle because people saw more milk production than 1520 liters/day "(RD, Government Actor 2).

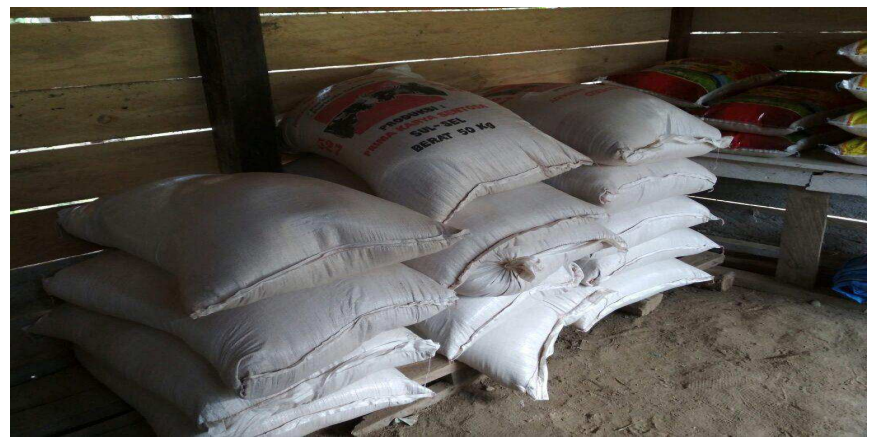

Fig. 1 Fodder

From the interview, informant showed that the local cattle used were from Java Island, which was the result of a crossbreed of Friesian Holstein (see Figure 2), which had a high level of milk production with a relatively low-fat content than other dairy cows. Therefore, dairy cows are the force of production.

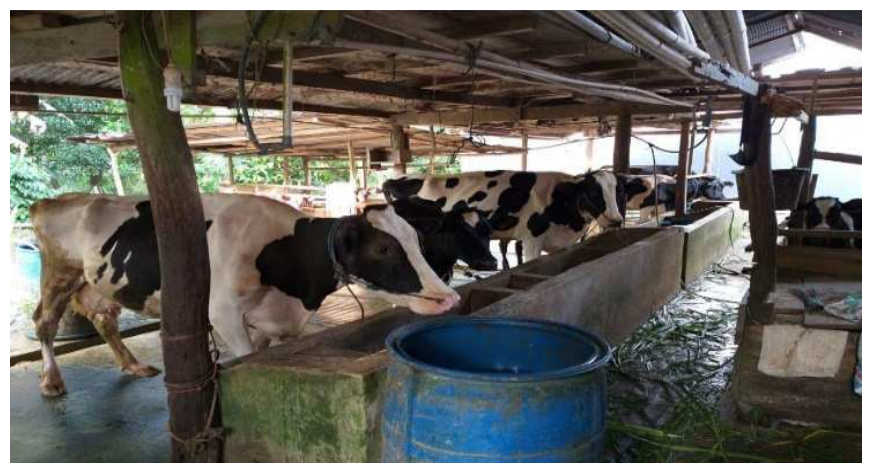

Fig. 2 Friesian Holstein Cow

"At first, I had a cage using a tent. At that time, I only had 1-2 dairy cows, and the cage was renovated several times and housed in the backyard, but it was not disturbing because livestock manure was used for biogas. For almost three years, I have used a permanent cage of $15 \times 5 \mathrm{~m}$ and made of brick and cement (RS, Farmer 7).

From the interview, the informant indicated that the cage was the force of production. The informant has a cage building, which is generally a simple permanent building measuring $15 \times 5 \mathrm{~m}$. The model of the cage building is made in half-open, the cage floor is made of cement so not slippery for easy cleaning, and the cage roof is made of zinc.

"The production tools of the dairy farm have not changed from the past until now. The used production tools for the shed and cattle needs are a shovel, hoe, plastic bucket, brush, and hose. Furthermore, we also utilize milk can, which is support from the government. Formerly, there was support in the form of the milking device. However, it was not used because we felt it was not effective, which was only able to be deployed for 3-6 cattle only, while after the milking process, the device should be sterilized and we did not have any time to do such activities" (HD, Farmer 10).

From interviews, the informants used simple production tools. The milking system carried out is generally still traditional, milking is done manually. Although there has been an introduction of technology in the form of an automatic milking device, it does not fit the business scale, farmers tend to prefer simple tools and do not incur high costs.

"To escalate productivity of dairy cattle in the Enrekang, the government delivers continuously training and skills for all groups of dairy cattle. Besides, technical assistance is intended to support an increase in national milk production. Our hope, a technical skill on how to raise dairy cattle will be getting good, which implicates increasing our cattle productivity will be more productive. About $60 \%$ contributors to the economic improvement of some welfare variables are livestock sectors" (JW, Government Actor 1).

From the interview above, that the force of knowledge of farmers is still relying on hereditary knowledge, even knowledge is obtained from farmers in the next village. Besides, farmers are given additional knowledge from the government by bringing experts in training activities, technical guidance, and counseling.

"From the beginning of starting this business until now, we had been provided training from local and central government. Further, we also had been visited Java Island to see the dairy farms there. Then, sometimes the dairy farmers from Java also had been invited to come here, Enrekang, and foreign tourist from various countries delivering their knowledge regarding with dairy farming, and eventually, we adopt their knowledge in practice until now, although, the condition here is not able to be equated with Java Island. Besides, we know how to manage dairy farming from the neighbor village, we learned together with other new farmers. While the Dangke making has been passed from generations" (HT, Farmer 12, and SN, Farmer 20).

From interviews shows, the informants obtained knowledge from generation to generation, technical guidance, and training from the government. The level of knowledge depends on whether the farmer accepts adoption from the training received or not. The results of capital training are taken for better business development going forward. In addition to training, farmers learn from previous experience, in the world of agriculture also requires the necessary expertise not obtained from science alone.

2) Production orientation: The orientation of production is a part of the force of production. Informants frequently talked about the orientation of production where there is an orientation shift from subsistence to commercial becoming a very common response in this research. From interviews, the informant's orientation of production began to shift from subsistence to commercial, such as commercial cake in Figure 3la. This shows that there is a change in the orientation of production based on meeting the basic needs of household members towards sales on the market. In this 
case, money becomes a target that must be achieved to meet the increasingly diverse needs of family members. It is ranging from primary needs such as food consumption, education, health to recreational needs, transportation, selfesteem, and freedom to actualize themselves and other secondary needs.

"I produced the initial production with its own consumption orientation, where milk was processed into Dangke and consumed for families because I wanted to try it, but later switched to a commercial orientation where we did not consume but marketed only at home" (JF, Farmer 13).

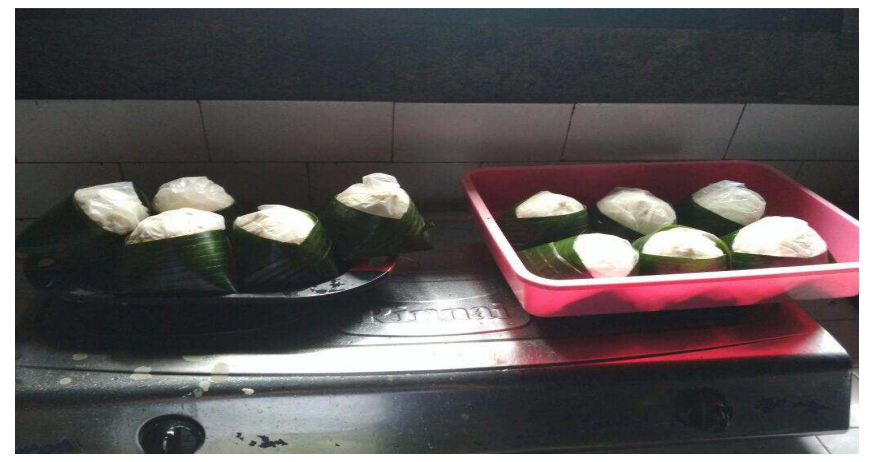

Fig. 3 Dangke

\section{B. Production Relation}

1) Labor division: Division of labor (see Figure 4) is an essential element in the relation of production. Labors play an essential role in raising dairy cattle in this familyindustrial farm-scale commonly both the head of a family involves as adult labor, and other family members such as wife and children work in helping to look after the cattle.

"The division of labor where I get a job in the cage (starting from looking for forage, cleaning the cage, and cattle, providing feed and water and collecting milk), and my wife takes part in the production and selling the products. So, we have already known our respective duties. Our children also often help us to clean the cage and collecting milk" (AM, Farmer 17).

From interviews, it shows that the division of labor in the family is between men and women. The division of labor is carried out in the activities of dairy farming, which is to start cleaning cages, taking manure, providing food and drinking, looking for grass, bathing cows, milking, and marketing milk. They have duties and responsibilities in the work they do. Likewise, for the wage system labor.

2) Relations in production organization: In a production organization, there is a relation between the actors of production both based on morals in one family and based on rationality. This is also an essential element in the social relations of production.

"In raising dairy cattle, I was with my family members who managed this business because there were few cows that I kept. So, we started in the morning looking for grass, bathing the livestock until cooking Dangke. We have shared the task so that it is finished quickly. Likewise, in the afternoon after the Asr prayer, we started working again, so it was done repeatedly. In work, there is no wage system because we have the view that this is for the benefit of a shared family (SF, Farmer 9).

From interviews, the informants used family labor. This is because, in addition to the existence of based on morals, they also do not have to spend money to pay wages and can be used for other vital needs. Based on the results of the interview, that in the maintenance of dairy cows where the informants use family labor and are assisted by labor outside because the family workforce is inadequate, and the scale of business continues to grow so that farmers must pay labor wages.

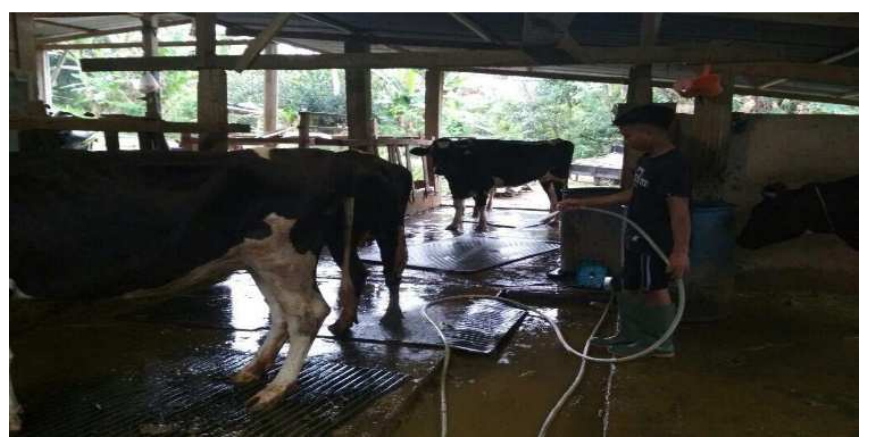

Fig. 4 Division of Labor

"Since my dairy cattle are keeping the increase, I start to employ extra laborers from outside of my core family members. I get employment from outside this regency. I use labor from outside by paying about IDR 1,500,000/month. So, the working system had been allocated to labor. However, I still monitor what they do. I also often involved looking for forage. All laborers have recognized their duties" (SN, Farmer 20).

In the context of the force of production can be discussed as follows. The land is part of the technology of production. The results of our study indicate the use of ex-agricultural land for a dairy farming business. This finding is supported by the study that land is a significant investment where each institution has its pattern in land management and has real rules that apply from generation to generation and cannot be changed by anyone [19]. In other studies, where changes in livelihoods due to the conversion of land use from agriculture to a variety of non-agricultural jobs led to an increase in household income [20]-[22]. Besides, our results show that feed is used by utilizing local feed potential both during the rainy season, dry season, and harvest season. A previous study reported similar findings in the central and non-central areas of dairy farming in Enrekang District that the use of rice straw and corn was only carried out during the dry season [23]. All farmers in the central area use peanut straw during the harvest season (end of the rainy season) because it can increase milk production significantly. This finding is supported by research that corn silage is the main feed for dairy farming and has a higher cost ratio [24]. Other research shows that it is necessary to utilize the incorporation of available fodder and supplements from the local feed. However, farmers need to have the skills can adapt by participating in farmer groups to be able to process good fodder [25].

In addition to land and fodder, our results show that the cattle used are from Java, which is the result of the 
crossbreed of Friesian Holstein. The cattle have considerable potential to be developed because it can produce higher milk production. This is supported by characteristics such as geographical conditions, ecology, and soil fertility. Friesian Holstein has higher lactation milk yield than Norwegian Red (NR) [26]. Production tools and cages are part of the technology of production. Our results show that the pattern of dairy farming is still traditional. This can be seen from the form of cages, and other production tools are simple. Smallscale farmers are interested in technology that is easily implemented, which has direct benefits [27].

Furthermore, knowledge is part of the forces of production in the development of dairy farming. The results of our research show that knowledge obtained from generation to generation, comparative study, training, and extension. Knowledge and technology need to be transferred from research to practice through education, training, demonstration, and guidance services for dairy farmers where other studies show the power that drives farmers to make innovation choices [28], [29].

The results of this study indicate that there are changes in the orientation of production from subsistence (own consumption) towards commercial (market sale). This finding is supported by the study's concerns on the transition from subsistence to commercial production, moving transition households [30]. Other studies pointing to infrastructure development and accessibility (market access, support, and services) are essential drivers underlying the commercialization of agriculture in the highlands. This leads to changes in upland livelihoods towards the market, with implications for household demographics, socioeconomic position, and income [31].

In the context of social relations of production can be discussed as follows. The results show that there is a simple division of labor in the dairy farming business. Labor who play a role in raising dairy cows on a family-scale farm, in general, are in addition to the involvement of the head of the family as an adult male workforce. Family members such as wives and children who participate in helping maintenance of dairy cows, starting from looking for and providing forage, concentrate, giving drink, bathing cattle, cleaning cages, milking, and marketing it. The same is true for the division of labor families outside. The relational approach will contribute to overcoming the situation and stability and allowing the transformation of changes in the pattern of employment relations [32]. The interest of both sexes in training related to livestock cultivation and management approaches shows the potential to improve household welfare and reduce gender differences [33].

The results show that there is a transition in social relations in the production organization. They viewed from social relations in the production organization based on morals in the family workforce-use of family labor to reduce production costs. As the scale of business increases, farmers use assistance from outside the family with a wage system. The presence of hired labor and family workforce can complement management tasks (which are specifically for the head of agriculture and family labor) and technical operations (the only operation carried out by wage labor) [34].

\section{The Specific Contribution of this Research}

This research contributed to literature and growing debates in the modernity era [35], [36]. The economic development and modernization involve cultural norm transformation where traditional norm becomes egalitarian, and trust tends to be changed by modern individualistic values [35]. Besides, agricultural households undergo a scarcity of cotter in operating forming. However, do not experience a lack of household-labor in the marketing of agricultural products [36]. Thus, existing research reflects its force of production based on advanced technology and based on profit in the orientation of production. This critical finding, related to the development of dairy farming, no one has explored the mode of production in the dialectical era of modernity. Our research shows that despite modernization, but the technology of production is still simple, and the orientation of production is limited to consumption and market, not to profit orientation. Likewise, the social relations of production still use the combination of moral and rationality based, not yet full rationality. The modernization is a process of political-economic transformation designed to better align agricultural production processes with the dynamics, needs, and the process of capital accumulation [37].

The government must be present to educate the public about the importance of fresh milk for fulfilling nutritional needs, to increase the level of milk consumption in Indonesia. The current condition of dairy farming in Indonesia in Indonesia is still maintained in Java, especially in the highlands. Meanwhile, the milk consumer community is spread throughout Indonesia both in the lowlands and highlands. We need to introduce dairy cows that are adaptive to lowland environments and develop dairy cows throughout the archipelago so that access to fresh milk is getting closer and more comfortable for the people to obtain,

Intact activities are needed and touch all aspects of dairy farming, ranging from livestock germs, feed, reproduction, milking, and milk quality so that, in the end, it will increase the income of dairy farmers. In addition to providing feed, livestock reproduction must be continuously improved through the handling of disturbances and optimization of reproduction so that a shorter Day Open and calving interval is obtained. The involvement of the relevant local offices must also be intensified to get better support and results.

Thus, breeding is no longer considered a side job, but it is a promising and attractive job for the younger generation so that it will encourage the emergence of young breeders who certainly have better abilities than the current breeders. With the increased entrepreneurial spirit of farmers, it will have an impact on increasing income and employment. Moreover, if it has developed into the milk processing industry, it will undoubtedly be an added value and will have an impact on increasing animal protein from milk. The point is that farmers must be prosperous, and the community will be able to fulfill their nutrition from animal protein sources.

\section{CONCLUSION}

Judged from the characteristics of the technology of production that are simple and orientation of production that are only for subsistence needs, it then concluded that the 
force of production of dairy farming is in the characteristic non-capitalistic. Then judged from the characteristics of a low division of labor and relation in production organization based on combination morality and rationality, it then concluded that social relations of production are also characterized by not capitalistic. Thus, the mode of production of dairy farming is a non-capitalistic mode of production. This research contributes to modernization theory that the process of modernization is not always followed by changes from non-capitalistic to the capitalistic mode of production.

Animal husbandry plays an important role in boosting the Indonesian economy. Therefore, development efforts in the livestock sector are needed so that the Indonesian economy can grow fast. We must always be responsive to the rapid changes that occur in the world around us. If we anticipate too late, then in the future, we will only be spectators and markets for commodities resulting from technology development. Besides, in the context of strengthening the economies of scale and institutional breeders, the government is also working on a series of policies, such as shifting the pattern of raising individual cows toward a group with a colony housing pattern so that it meets diary farmers' wellbeing. Production mode also plays an essential role in helping to increase output per unit of labor. Through innovation and technology, labor productivity is expected to increase. With the maximum utilization of technology in development in the livestock sector, Indonesia's exports will run fast.

\section{ACKNOWLEDGMENT}

The authors are grateful to the local dairy raisers, the District of Animal Husbandry Officer, and the Enrekang District Head of Fisheries and Livestock Services Office for their willingness to provide support during the survey. This study was funded by the Ministry of Research, Technology, and Higher Education.

\section{REFERENCE}

[1] B. Guntoro et al., "Marketing and Institutional Characteristics of Dairy Industry in Indonesia," Int. J. Environ. Agric. Res., vol. 2, no. 3, pp. 106-114, 2016.

[2] P. Data, S. Informasi, P. Sekretariat, and K. Pertanian, "Outlook Susu," Kementerian Pertanian., 2017.

[3] G. Carrosio, "Energy production from biogas in the Italian countryside: Modernization vs. repeasantization," Biomass and Bioenergy, vol. 70, pp. 141-148, 2014.

[4] L. Paura and I. Arhipova, "Analysis of the Milk Production and Milk Price in Latvia," Procedia Econ. Financ., vol. 39, no. November 2015, pp. 39-43, 2016.

[5] Y. Wang and Q. Zhou, "Evaluation of Development of Agricultural Modernization in Central China," IERI Procedia, vol. 4, pp. 417424, 2013.

[6] J. Bewley, R. W. Palmer, and D. B. Jackson-Smith, "Modeling Milk Production and Labor Efficiencyin Modernized Wisconsin Dairy Herds," J. Dairy Sci., vol. 84, no. 3, pp. 705-716, 2001.

[7] C. Brown and S. Waldron, "Agrarian change, agricultural modernization and the modelling of agricultural households in Tibet," Agric. Syst., vol. 115, pp. 83-94, 2013.

[8] G. Bahiigwa, D. Rigby, and P. Woodhouse, "Right target, wrong mechanism? Agricultural modernization and poverty reduction in Uganda," World Dev., vol. 33, no. 3, pp. 481-496, 2005.

[9] A. Kearns, M. J. McKee, E. Sautkina, J. Cox, and L. Bond, "How to mix? Spatial configurations, modes of production and resident perceptions of mixed tenure neighbourhoods," Cities, vol. 35, pp. 397-408, 2013
[10] Z. Hong, C. Chu, and Y. Yu, "Dual-mode production planning for manufacturing with emission constraints," Eur. J. Oper. Res., vol. 251, no. 1, pp. 96-106, 2016.

[11] J. M. Grutter and H. P. Egler, "From cleaner production to sustainable industrial production modes," J. Clean. Prod., vol. 12, no. 3, pp. 249-256, 2004.

[12] L. Zhang and Y. Kong, "Optimization of Mixed Collaborative Distribution with Different Production Modes," J. Transp. Syst. Eng. Inf. Technol., vol. 12, no. 1, pp. 17-23, 2012.

[13] C. T. Zhang, H. X. Wang, and M. L. Ren, "Research on pricing and coordination strategy of green supply chain under hybrid production mode," Comput. Ind. Eng., vol. 72, no. 1, pp. 24-31, 2014.

[14] K. Moen and A. L. Middelthon, Qualitative Research Methods. Elsevier Ltd, 2015.

[15] A. Tong, W. C. Winkelmayer, and J. C. Craig, "Qualitative research in CKD: An overview of methods and applications," Am. J. Kidney Dis., vol. 64, no. 3, pp. 338-346, 2014.

[16] Virginia Braun1 aVirginia Braun1 a and Victoria ClarkeVictoria Clarke, "Using thematic analysis in psychology," Qual. Res. Psychol., vol. 3, no. 2006, pp. 77-101, 2006.

[17] H. G. Ridder, M. B. Miles, A. Michael Huberman, and J. Saldaña, "Qualitative data analysis. A methods sourcebook," Zeitschrift fur Pers., vol. 28, no. 4, pp. 485-487, 2014.

[18] K. Barclay et al., "The importance of qualitative social research for effective fisheries management," Fish. Res., vol. 186, pp. 426-438, 2017.

[19] N. Mappa, D. Salman, A. R. Siregar, and M. Arsyad, "Institutional Land Mastery Rotating, Pattern of Purchase Right Land Tenure," vol. VI, no. Iii, pp. 78-82, 2018.

[20] T. H. T. Nguyen, V. T. Tran, Q. T. Bui, Q. H. Man, and T. de V. Walter, "Socio-economic effects of agricultural land conversion for urban development: Case study of Hanoi, Vietnam," Land use policy, vol. 54, pp. 583-592, 2016.

[21] M. Piquer-Rodríguez et al., "Drivers of agricultural land-use change in the Argentine Pampas and Chaco regions," Appl. Geogr., vol. 91, no. June 2017, pp. 111-122, 2018.

[22] E. Ustaoglu, C. Perpiña Castillo, C. Jacobs-Crisioni, and C. Lavalle, "Economic evaluation of agricultural land to assess land use changes," Land use policy, vol. 56, pp. 125-146, 2016.

[23] S. Baba, A. Muktiani, A. Ako, and M. I. A. Dagong, "Keragaman dan Kebutuhan Teknologi Pakan Peternak Sapi Perah di Kabupaten Enrekang," Media Peternak., vol. 34, no. 2, pp. 146-154, 2011.

[24] H. Fathollahi, S. H. Mousavi-Avval, A. Akram, and S. Rafiee, "Comparative energy, economic and environmental analyses of forage production systems for dairy farming," J. Clean. Prod., vol. 182, pp. 852-862, 2018.

[25] N. N. Laila, A. F. Wijaya, and F. Amin, "Business Strategy of Cattle farmers and Bottleneck in Production under The Rise in Beef Price: A Case Study in Malang District," Jurnal Ilmiah Administrasi Publik (JIAP), vol. 3, no. 3, pp. 220-229. 2017

[26] C. P. Ferris, D. C. Patterson, F. J. Gordon, S. Watson, and D. J. Kilpatrick, "Calving traits, milk production, body condition, fertility, and survival of Holstein-Friesian and Norwegian Red dairy cattle on commercial dairy farms over 5 lactations," J. Dairy Sci., vol. 97, no. 8, pp. 5206-5218, 2014.

[27] C. G. Martínez. S.J. Ugoretz, C. M. Arriaga, M. A. Wattiaux, "Farm, household, and farmer characteristics associated with changes in management practices and technology adoption among dairy smallholders." Tropical Animal Health and Production., vol. 47, no. 2, pp. 311-316., 2014.

[28] J. Zhao, Z. Bai, and L. Ma, "Dairy farming in China at a crossroad," Sci. Bull., 2018.

[29] A. Rieple and S. Snijders, "The role of emotions in the choice to adopt, or resist, innovations by Irish dairy farmers," J. Bus. Res., vol. 85, no. April 2017, pp. 23-31, 2018.

[30] R. H. Behnke, "Measuring the benefits of subsistence versus commercial livestock production in Africa," Agricultural Systems, vol.16, no. 2, pp. 109-135, 1985.

[31] C. M. Hepp, C. M. T. Bech Bruun, and A.D Neergaard. "Transitioning towards commercial upland agriculture: A comparative study in Northern Lao PDR," NJAS - Wageningen Journal of Life Sciences, pp 1-9. 2018

[32] I. Darnhofer, C. Lamine, A. Strauss, and M. Navarrete, "The resilience of family farms: towards a relational perspective," J. Rural Stud., vol. 44, pp. 111-122, 2016.

[33] S. Xenarios, K. R. Kakumanu, U. S. Nagothu, and G. R. Kotapati, "Gender differentiated impacts from weather extremes: Insight from 
rural communities in South India," Environ. Dev., vol. 24, no. May, pp. 156-169, 2017.

[34] P. Dupraz and L. Latruffe, "Trends in family labour, hired labour and contract work on French field crop farms: The role of the Common Agricultural Policy," Food Policy, vol. 51, pp. 104-118, 2015.

[35] R. Haagsma and P. V. Mouche, "Egalitarian norms, economic development, and ethnic polarization," J. Comp. Econ., vol. 41, no. 3, pp. 719-744, 2013.
[36] A. Ukaro Ofuoku and B. Chuks Uweru, "Effects of Human Trafficking on Household Farm Labor Availability Among Arable Farming Households in Delta State, Nigeria," J. Northeast Agric. Univ. (English Ed., vol. 23, no. 3, pp. 70-78, 2016.

[37] J. D. Van der Ploeg, "From de-to repeasantization: The modernization of agriculture revisited”. Journal of Rural Studies, vol 61, pp. 236-243. 2018. 